\title{
The Effects of the Internet on Celebrification and Mental Health: From Britney Spears to the Vatican
}

\author{
Cameron J Sabet \\ University of Pennsylvania, Alexandria, VA, USA
}

*Corresponding author: Cameron J Sabet, University of Pennsylvania, 5130 Duke Street Suite 9, Alexandria, VA 22312, USA

\begin{abstract}
Though superficially secular, celebrification is an intrinsically religious phenomenon. Though celebrities fashion mighty podiums out of public personas of otherness, these platforms of deification can also quickly become their public gallows. Cyclical religious themes like idolization, impersonation, sacrifice, and redemption shape the career arcs and mental health of many high-profile figures because society craves drama. Therefore, this analysis will explore how digital media mediates and expedites cycles of sacrifice and redemption with secular and religious icons and institutions alike by increasing the resolution of private life and exposing fissures in supposedly airtight public appearances.
\end{abstract}

\section{Introduction}

Celebrities are not human in the world of popular culture. They are cultural deities. In her literary work Imagining Celebrity, author Kathryn Lofton asserts that "In American culture, the celebrity functions as a component of a pantheon that exists to dramatize social concerns, endorse certain forms of normative behavior, and fulfill narrative fantasies of an inchoate, disconnected, and ostensibly secular public" [1]. Each celebrity specializes on a certain aspect of popular culture and becomes the god of it. When these celebrities unite in their Mount Olympus - Hollywood - they collectively influence culture in the same way the Greek gods control the mortal world. Lofton further explains how "Individuals might identify with (even impersonate) a beloved celebrity... [This] shows how celebrity has become a form of ritual practice, moral commentary, and identity development in ways [that] correlate to religious behavior" [1]. Britney Spears, for example, was once a cultural goddess: Her name was omnipresent in daily life across America in the 1990s. Lofton explores her quasi-religious following by noting how "Britney [is] an economy... a solicitation for a cosmetic procedure, a scent, an imagined horde of cameras, and an impersonation. She is background music and an iTunes accessory" [1]. In this sense, the name Britney itself implies celebrity life in the same way Jesus Christ implies piety, generosity, and kindness. Britney appears as a cultural deity in daily life when, for example, her music influences consumer choices like purchasing cosmetic products when played in a beauty salon. Lofton's initial exploration of the dialectic of celebrity and society here reveals how secular deities maintain powerful grips on culture through omnipresence in daily life.

However, cultures also maintain similarly powerful grips on celebrities. The public asked for Britney Spears to be a perfect woman. The masses expected her to represent the competing ideals of virginity and promiscuity throughout her career. By holding her to such impossible expectations, society set a time limit for her success. Eventually, she would have to fail these ideals and be exposed as a flawed human being. Britney, in a sense, stepped on the pedestal of celebrity and ignored the noose around her neck. Furthermore, society primed her for ritual sacrifice by treating her well. Paralleling traditional sacrificial rituals, the masses showered Britney with attention and special treatment. Her net worth soared to well over 70 million dollars in 2003 and her booked packed shows back to back. The masses similarly hailed Jesus as their liberator when he entered Jerusalem, laying palm fronds before his

Citation: Sabet CJ (2021) The Effects of the Internet on Celebrification and Mental Health: From Britney Spears to the Vatican. Int Arch Public Health Community Med 5:065. doi.org/10.23937/26434512/1710065

Accepted: October 07, 2021; Published: October 09, 2021

Copyright: (C) 2021 Sabet CJ. This is an open-access article distributed under the terms of the Creative Commons Attribution License, which permits unrestricted use, distribution, and reproduction in any medium, provided the original author and source are credited. 
path. However, these same crowds turned on him only a week later and demanded his crucifixion. Similarly, when Britney inevitably broke her perfect outward appearance, the crowds that attended her shows soon craved her catharsis of her sacrifice. Her followers read "tabloids in a particular ritual manner" that began highlighting her shocking "custody battles and drug problems" [1]. This hypocritical behavior reveals one unexplored point of tension throughout Lofton's analysis: If we live vicariously through our icons, why do we crave their destruction? We do so because it distracts from personal problems and provides entertainment centered on schadenfreude. We live vicariously through our icons' successes but nonetheless predicate our success on the failure of others. We killed Jesus Christ, according to atonement theory, to save ourselves. When an icon falls, everyone else rises. Therefore, their suffering is a cause for celebration.

However, society wishes to see its icons repeat this narrative cycle of ascendancy and descendancy, not merely stay dormant in one state. Therefore, Lofton highlights how sacrifice must balance with the equally cathartic motif of redemption to complete this cycle of perpetual drama and keep the public invested. Throughout Britney's downfall, for example, the senior pastor of an 8,000-member mega church in Kentucky urged his followers to send her "'letters of love and support'... 'No preaching'. No criticizing. Just love. As a church, let's love Britney the way Jesus loves her'" [1]. Practically speaking, however, life can rarely fit into such perfect stories. Despite people's best efforts to revive her former confidence, impossible ideals shattered her character irreparably. She suffered a nervous breakdown, shaved her head, and fled the spotlight with no particularly redemptive events following thereafter. Similarly, Jesus is expected to return in The Last Judgment, but he has yet to complete this narrative arc. The dialectic of disaster and return in Britney and Jesus' narrative arcs is either too improbable or too lengthy for the masses to wait for its completion with bated breaths. Therefore, without religious traditions to extend the patience of the masses and keep the stories alive as they do with Jesus, the public gradually lost interest in Britney.

Unlike Britney's case in Hollywood, however, the Vatican has a vested interest in maintaining religious authority and relevance in society. Therefore, this institution works to carefully conceal scandals involving religious leaders from the public eye to preserve its moral standing. Centuries before the rise of digital media, the Vatican could maintain enough privacy and distance from the public to maintain a clean outward appearance. However, the rise of digital media now makes it difficult to hide scandals from public oversight. For example, when the Boston Globe Newspaper "exposed widespread [sexual] abuse and how pedophile priests were moved around by [Catholic] leaders instead of being held accountable... people came forward across the US and around the world [to report more and more cases]" [2]. Media now exposes every crevice of society; even established religious institutions are unspared from the watchful eyes of digital technology. The Vatican must now balance centuries-old traditions of confidentiality with the radical transparency of modern digital media technologies to stay relevant while maintaining a respectable public face. If this institution can satisfy society's craving for redemption by enacting progressive reforms and methods of accountability, digital media will again report on such changes and facilitate the completion of the narrative cycle of sin and redemption. Unlike the stories of Jesus and Britney, this cycle most likely can approach completion within our lifetimes, since Pope Francis recently issued a law "obligating officials in the Roman Catholic Church worldwide to report cases of clergy sexual abuse - and attempts to cover it up - to their superiors". However, this arc of redemption remains predictably incomplete since the law does not "require church officials to report abuse accusations to the police and prosecutors" [3]. This highlights the Vatican's dilemma between transitioning their previously unchecked institution into our transparent modern digital mediasaturated landscape while still maintaining centuriesold traditions of secrecy and an outward appearance of moral integrity. In this sense, digital media technology mediated the downfall and, to an extent, catalyzed the redemption of the Vatican's reputation in the modern public sphere.

Technology mediates and expedites the dramatic cycle of destruction and redemption that society craves. From Hollywood to the Vatican, digital media technology seeps into private life from all angles and exposes previously unseen events where icons stumble over ideals backstage. From Britney's nervous breakdown to accounts of pedophilia in the Catholic Church, exposed flaws can destroy the reputations of internationally renowned celebrities and centuries-old religious institutions alike. But although society welcomes negative drama, the masses value redemption equally. In this light, technology similarly serves as an avenue to reveal, for example, progressive legislative steps that heighten methods of accountability within the Catholic religious order to complete the cycle with redemption. However, now that the Vatican's airtight veneer has been stripped away, some Catholics have weakened their affiliations with the institution. This completion feeds into society's craving for drama and repositions these figures for ritualistic sacrifice through digital mediums once again. This leaves millions worldwide at risk of existential and mental health crises as they struggle for meaning outside their traditional cultures. For further research, it is worth exploring the response of the Catholic community to such allegations, and their thoughts on the effect of social media on human institutions originally perceived as infallible. 


\section{References}

1. Lofton K (2017) Consuming Religion. ProQuest Ebook Central, University of Chicago Press.
2. BBC News (2019) Catholic Church child sexual abuse scandal.

3. Horowitz J (2019) Pope issues first rules for Catholic Church worldwide to report sex abuse. The New York Times. 